New insights from XRF core scanning data into boreal lake ontogeny during the Eemian (Marine Isotope Stage 5e) at Sokli, northeast Finland

Kylander, Malin E.

2018-01

Kylander , M E , Plikk , A , Rydberg , J , Löwemark , L, Salonen , J S , Fernandez-Fernandez , M \& Helmens , K 2018 , ' New insights from XRF core scanning data into boreal lake ontogeny during the Eemian (Marine Isotope Stage $5 \mathrm{e}$ ) at Sokli, northeast Finland ', Quaternary Research, vol. 89 , no. 1 , pp. 352-364 . https://doi.org/10.1017/qua.2017.84

http://hdl.handle.net/10138/326392

https://doi.org/10.1017/qua.2017.84

cc_by_nc_nd

acceptedVersion

Downloaded from Helda, University of Helsinki institutional repository.

This is an electronic reprint of the original article.

This reprint may differ from the original in pagination and typographic detail.

Please cite the original version. 


\section{New Insights from XRF Core Scanning Data into Boreal Lake 2 Ontogeny During the Eemian (MIS 5e) at Sokli, NE Finland}

3 Malin E. Kylander ${ }^{1,2}$, Anna Plikk²,3, Johan Rydberg 4 , Ludvig Löwemark ${ }^{5}$, J. Sakari

4 Salonen ${ }^{6}$, María Fernández-Fernández ${ }^{7}$, and Karin Helmens ${ }^{2,3}$

5 'Department of Geological Sciences, Stockholm University, SE-10691 Stockholm, Sweden Tel: +46

6 (0)8-674 7898; Fax: +46 (0)8-674-7897

$7 \quad{ }^{2}$ The Bolin Centre for Climate Research, Stockholm University, SE-10691 Stockholm, Sweden

8 3Department of Physical Geography, Stockholm University, SE-10691 Stockholm, Sweden

9 4Department of Ecology and Environmental Sciences, Umeå University, SE-901 87 Umeå, Sweden

10 5Department of Geosciences, National Taiwan University, 106 17, Taipei, Taiwan

11 'Department of Geosciences and Geography, FI-00014 University of Helsinki, Finland

12 7Instituto de Investigaciones Agrobiológicas de Galicia, CSIC, Apartado 122, E-15780 Santiago de

13 Compostela, Spain

14 corresponding author: malin.kylander@geo.su.se

15 Key words: Eemian, XRF core scanning, geochemistry, lake sediment, boreal, ontogeny 
17 Biological proxies from the Sokli Eemian (MIS 5e) paleolake sequence from NE

18 Finland have previously shown that, unlike many postglacial records from boreal

19 sites, the lake becomes increasingly eutrophic over time. Here, principal

20 components (PC) were extracted from a high resolution multi-element XRF core

21 scanning dataset to describe minerogenic input from the wider catchment (PC1),

22 the input of S, Fe, Mn, and Ca-rich detrital material from the surrounding Sokli

23 Carbonatite Massif (PC2), and chemical weathering (PC3). Minerogenic inputs to

24 the lake were elevated early in the record and during two abrupt cooling events

25 when soils and vegetation in the catchment were poor. Chemical weathering in

26 the catchment generally increased over time, coinciding with higher air

27 temperatures, catchment productivity, and the presence of acidic conifer species.

28 Abiotic edaphic processes play a key role in lake ontogeny at this site stemming

29 from the base cation- and nutrient-rich bedrock, which supports lake alkalinity

30 and productivity. The climate history at this site, and its integrated effects on the

31 lake system, appear to override development processes and alters its long-term

32 trajectory. 


\section{Introduction}

The last interglacial, the Eemian (roughly equivalent to Marine Isotope Stage (MIS) 5e, ca. 130-115 ka ago), was a time when certain regions of the world experienced a warmer-than-present climate. While studies from temperate central Europe suggest that the Eemian was climatically rather stable, experiencing only minor short-term variability ( Cheddadi et al., 1998; Kühl et al., 2007; Rioual et al., 2007; Bińka et al., 2011), records from northern Europe and the North Atlantic region have registered pronounced Eemian climate changes, seen as cooling and aridity pulses (Cortijo et al., 1994; Seidenkrantz et al., 1995; Fronval and Jansen, 1996; Björck et al., 2000; Bauch et al., 2011; Irvalı et al., 2012; Galaasen et al., 2014). Due to glacial erosion at high latitudes, Eemian sequences are rare at boreal sites in northern Europe. An exception to this is the thick and continuous Eemian lake sediment sequence from Sokli, NE Finland. This sedimentation basin was formed through the action of ice and water working along a fracture zone bisecting the Sokli Carbonatite Massif (SCM), a carbonatite-alkaline intrusion in the crystalline Precambrian Shield (Vartiainen, 1980).

Palynological analysis first proposed an Eemian age for the diatom gyttja deposit (Ilvonen, 1973) found between 25 and 16 m of depth at Sokli. The bracketing glaciofluvial sands and gravel (28.5 and $25 \mathrm{~m}$ ) and fluvial sands (16 to $13 \mathrm{~m}$ ) were later dated by thermoluminescence (TL) and infrared stimulated luminescence (IRSL) to >ca. $110 \mathrm{ka}$ and <ca. 150-180 ka, respectively (Helmens et al., 2000; 2007). Additional optically stimulated luminescence (OSL) dating of the upper fluvial sands revealed an age >ca. 95 ka (Alexanderson et al., 2008). 
While an absolute chronology for this sequence is unavailable, previous studies have divided the lake development into five main phases: glacio-lacustrine, early-, early mid-, late mid-, and late-Eemian (Plikk et al., 2016). Superimposed on these phases are two abrupt climate change events (Helmens et al., 2015; Plikk et al., 2016). The earlier event reveals a cooling similar to that seen in the North Atlantic Ocean (Bauch et al., 2011; Irvalı et al., 2012; Galaasen et al., 2014). Occurring after full interglacial conditions were reached, the "Tunturi event" saw summer temperatures drop $2-4^{\circ} \mathrm{C}$ over a time frame of ca. $500-1000$ years. Similarly, the later event implies cooler and drier conditions at Sokli (Helmens et al., 2015; Plikk et al., 2016).

Reconstructing past paleoenvironmental change using postglacial lake sediments must consider a lake's natural development, or ontogeny, as well as the external climate signal we are often trying to capture. Studies in boreal landscapes on late glacial/Holocene and recent timescales suggest a common pattern towards natural oligotrophication over time. After ice retreat the catchment is stabilized through the gradual build-up of soils and colonization by vegetation. In boreal regions this vegetation typically sees the transition from Betula to more acidic Pinus and Picea conifer species (Donner, 1995). The growing catchment vegetation also retains more nutrients, making them unavailable for lake biota. Soluble minerals in the soils and exposed bedrock surfaces (e.g., apatite, biotite, hornblende) are weathered and base cations are consumed, leading to the loss of alkalinity in the lake water. As soil organic matter (SOM) and dissolved organic carbon (DOC) in the catchment increase there is an influx of increasingly acidic water to the lake. These effects can be further enhanced by the inhibition of groundwater recharge by hardened soil 
horizons; this reduces contact with the bedrock and soils, and therefore leaching of base cations, and increases flow through humic-rich soils (Ford, 1990; Pienitz et al., 1999; Engstrom et al., 2000; Fritz et al., 2004; Boyle, 2007; Fritz and Anderson, 2013; Law et al., 2015).

In contrast to the pattern commonly seen at boreal sites, previous studies based on biological proxies (diatoms, pollen, biogenic silica (BSi), total organic carbon (TOC), chironomids) show that the lake at Sokli becomes increasingly eutrophic over time (Helmens et al., 2015; Plikk et al., 2016). Within the literature, there is a discussion as to the relative importance of abiotic and biotic processes to lake development. Most studies have however, been restricted to lakes in base cation-poor and mixed terrains (e.g., Whitehead et al., 1989; For 1990; Pienitz et al., 1999; Engstrom et al., 2000; Fritz et al., 2004; Law et al., 2015) or modelling exercises (Boyle, 2007). Sokli differs from a typical boreal lake in that it sits in the base cation-rich SCM, providing us with an alternative geological, and therefore abiotic, setting in which to examine postglacial boreal lake ontogeny. The elemental chemistry of the sediments is controlled by the interplay between the geology, hydrology, and biology of the lake and its catchment and the external climate changes. We use Principal Component Analysis (PCA) and supporting ratio and correlative tools (e.g., Kylander et al., 2011; Ljung et al., 2015) from a high-resolution XRF core scanning dataset to reveal detail about ontogeny relevant processes, such as soil development/erosion, nutrient and base cation supply, and productivity. We then place these processes into context by comparing with previously published proxy data and attempt to understand what factors control the unusual lake ontogeny at Sokli. 


\section{Materials and Methods}

109 Sampling Site

110 Sokli $\left(67^{\circ} 48^{\prime} \mathrm{N}, 2^{\circ} 18^{\prime} \mathrm{E}\right)$, surface elevation $220 \mathrm{~m}$ a.s.l., is situated in the SCM

111 located in NE Finland (Figure 1A). The present day climate around Sokli is cold

112 boreal with a mean annual temperature of $1^{\circ} \mathrm{C}$ and annual precipitation averages

113 between $500-550 \mathrm{~mm} \mathrm{yr}^{-1}$ (Drebs et al., 2002). The vegetation is northern boreal

114 forest and mires are widespread in the area. Soils in the region are generally

115 composed of acidic podzol soils.

116 The carbonate-rich magma intrusion of the SCM penetrated through the

117 crystalline Precambrian Shield about 350 Ma ago. Today, the deeply eroded

118 carbonatite intrusion forms a circular depression, ca. $5 \mathrm{~km}$ in diameter,

119 surrounded by a hilly ring of fenites (up to $320 \mathrm{~m}$ a.s.l.)(Figure 1B). Dispersed

120 residual phosphorous deposits can be found across the carbonatite bedrock

121 (Talvitie et al., 1981). The deeper part of the depression is now infilled with

122 sedimentary deposits, the thickest of which are found in a string of hollows

123 extending along a NE-SW trending fracture valley that crosses the SCM. The

124 sequence studied here is from the Sokli 2010/4 borehole which was retrieved by

125 percussion drilling in March 2010 by the Geological Survey of Finland.

\section{Sample Analysis}

127 After retrieval all sediment cores were described in the laboratory. Prior to any

128 sub-sampling, the sediments were scanned at the SLAM Lab at the Department of

129 Geological Sciences, Stockholm University, using an ITRAX XRF Core Scanner

130 from Cox Analytical Systems (Gothenburg, Sweden). Analyses were made using a

131 Mo tube set at $30 \mathrm{kV}$ and $45 \mathrm{~mA}$ with a step size of $2.5 \mathrm{~mm}$ and a dwell time of 60 
132 s. Based on analytical performance (counting statistics above background),

133 reliable data was acquired for $\mathrm{Si}, \mathrm{S}, \mathrm{K}, \mathrm{Ca}, \mathrm{Ti}, \mathrm{Mn}, \mathrm{Fe}, \mathrm{Rb}, \mathrm{Sr}$, and $\mathrm{Zr}$. All data

134 presented here are normalized to the (incoherent+coherent) scattering to

135 remove various instrumental effects and then smoothed using a 5-point running

136 mean to capture the main shifts. Full analytical details of BSi, TOC, siliceous

137 microfossil, and pollen analyses can be found in Plikk et al. (2016).

\section{$138 \quad$ Statistical Methods}

139 Data interpretation was aided by PCA, which was made using JMP 9.0.0 software

140 in correlation mode using a Varimax rotation. Before analysis all data were

141 converted to Z-scores calculated as $\left(\mathrm{X}_{\mathrm{i}}-\mathrm{X}_{\mathrm{avg}}\right) / \mathrm{X}_{\text {std }}$, where $\mathrm{X}_{\mathrm{i}}$ is the normalized

142 elemental peak areas and $\mathrm{X}_{\mathrm{av}}$ g and $\mathrm{X}_{\text {std }}$ are the series average and standard

143 deviation, respectively, of the variable $\mathrm{X}_{\mathrm{i}}$. This was done to avoid scaling effects

144 and to obtain average-centred distributions (Eriksson et al., 1999). All principal

145 components (PCs) with Eigenvalues above 1 were extracted. In order to reduce

146 the amount of data manipulation when making correlations between data of

147 different resolution, a single XRF core scanning data point was selected for

148 matching TOC, TIC, and BSi sample depths.

\section{Results}

\section{Stratigraphy}

151 The sediment between 25 and $16 \mathrm{~m}$ is mainly comprised of diatom gyttja, which

152 is divided into thirteen units based on the stratigraphy and sediment properties.

153 Due to the open core head during drilling several cores were compressed but

154 this has been corrected for in the stratigraphic column presented here. Note that 
this compression may have affected the visibility of some laminations, namely in Units C, F, G, and H. Details of the compressed sections are given in Plikk et al. (2016).

The lowermost Unit A (25.00-23.41 m) consists of partly laminated brown gyttja with thin yellowish laminations (Figures 2-5). In Unit B (23.41$23.33 \mathrm{~m}$ ) laminations stop and the diatom gyttja becomes distinctly more silty. The beginning of Unit C (23.33-21.50 $\mathrm{m})$ is composed of silty diatom gyttja. Laminations disappear in the diatom gyttja between 22.75-22.25 m. Partly laminated brown gyttja is found above this layer which is replaced again by a homogenous diatom gyttja. Unit D (21.50-21.00 m) consists of dark brown gyttja with thin yellowish laminae and $1 \mathrm{~cm}$ thick dark bands every 5-10 $\mathrm{cm}$. In the upper part of the unit the thin laminae become slightly distorted (21.20-21.00 $\mathrm{m})$. In Unit E (21.00-20.73 m) the diatom gyttja is vaguely laminated and slightly reddish. The sediment was disturbed during coring between 20.73-20.50 m and is not considered. Unit F (20.50-19.86 m) has light brown gyttja with less distinct and more sporadic laminations. With the transition to Unit G (19.86$19.50 \mathrm{~m}$ ) the laminations disappear. Instead, this unit consists of darker brown homogeneous gyttja. Unit H (19.50-17.41 m) consist of brown homogeneous gyttja although dark laminations were observed during coring. In Unit I (17.41$17.33 \mathrm{~m})$, the gyttja once again becomes silty. In Unit J (17.33-17.07 m) the homogeneous brown gyttja is spotted with light yellow granules. Unit K (17.07$16.75 \mathrm{~m}$ ) shows a gradual transition into a light grey-reddish spotted diatom gyttja. Unit L (16.75-16.58 m) is the last unit consisting of brown homogeneous diatom gyttja. Unit M (16.58-16.00 m) consists of ca. $10 \mathrm{~cm}$ thick layers of brown gyttja with small yellowish spots intercalated with five 2-3 cm thick layers of 
181 uppermost $20 \mathrm{~cm}$ the gyttja is sandy.

\section{XRF Core Scanning Data}

In a paleoclimatic context, it is the relative changes in the elemental XRF core scanning profiles, rather than the absolute concentrations, that are of interest. XRF core scanning analyses can be negatively affected by large variations in the matrix (Chawchai et al., 2016). At Sokli the studied sediments are mainly composed of gyttja, which reduces the importance of matrix effects on the data. With the aim of reconstructing paleoenvironmental change at Sokli, the acquired data were used in a PCA. The raw data are presented in the Supplementary Information and can be downloaded from www.bolin.su.se/data/xxx.

\section{PCA, Total Organic Carbon, and Elemental Ratios}

Three main PC explain $81 \%$ of the variance in the data (Table 1). The first component (PC1), explaining $42 \%$ of the data, is associated with $\mathrm{K}, \mathrm{Ti}, \mathrm{Rb}, \mathrm{Zr}, \mathrm{Si}$, and Ca (Table 2). PC2 explains $26 \%$ of the variance in the data and is associated with S, Fe, Ca, and Mn. PC3 explains 13\% of the variance in the data linked to the behaviour of $\mathrm{Sr}$ and Ca.

The plotting of PC factors scores by depth indicates when the processes described by the PC are more intense (having more positive values) or less intense (having more negative values). PC1 factor scores are slightly elevated at the base of Unit A and then decrease towards the middle of the unit, fluctuating around a value of zero (Figure 2). PC1 factors scores peak at the end of the unit at $23.55 \mathrm{~m}$. A second peak is observed at the transition to Unit B at $23.41 \mathrm{~m}$ in the 
siltier layer. In Unit C factor scores decrease slightly from the base but remain

204 just below zero up into Unit H. High positive values are observed in Unit I, again

205 coinciding with a siltier layer. Peaks in PC1 are observed in Unit M matching with

206 visible sand layers. Although the TOC data is much lower resolution (n=102 vs.

$207 \mathrm{n}=2404)$, PC1 and TOC are significantly negatively correlated $(r=-0.57, n=102$,

$208 p=0.001)$

209 For PC2 the highest and largest amplitude changes in factor scores are

210 found overprinted on an overall decreasing trend in Unit A (Figure 3). This is

211 capped by a large peak in Unit B. From Unit C through to Unit H factor scores are

212 slightly negative with occasional positive incursions and the frequency of the

213 shifts generally tightens moving up the profile. The lowest PC2 factor scores of

214 the profile are seen at the boundary of Units J and $\mathrm{K}$ while values increase up into

215 Unit L. Peaks observed in Unit M are slightly out of phase with the sand layers.

216 PC2 is significantly negatively correlated with inferred values of BSi from FTIR-

217 measurements $(\mathrm{r}=-0.57 ; \mathrm{n}=802 ; \mathrm{p}$-value $<0.001)$.

218 In general PC3 factor scores are negative in Unit A (Figure 4). PC3 factor

219 scores peak in Unit B while Unit C initially has the lowest factor scores of the

220 profile. From Unit D through to Unit $\mathrm{H}$ there is a long-term trend towards

221 increasingly positive values. At the top of Unit $\mathrm{H}$ positive values are reached and

222 more prominent peaks are observed. PC3 factor scores increase in Unit I and

223 then decrease in Units J and K; this trend is reversed in Unit L. In Unit M peaks in

224 PC3 occur for the most part at the same time as the sand layers. PC3 is positively

225 correlated to inferred values of total inorganic carbon (TIC) from FTIR-

226 measurements ( $r=0.58 ; n=851 ; p$-value <0.001; Rosén et al. 2010). 

seen in the profile at the transition into Unit B (Figure 4). From this unit upwards $\mathrm{Si} / \mathrm{Ti}$ gradually increases peaking at the top of Unit E. An apparent decrease in $\mathrm{Si} / \mathrm{Ti}$ occurs in Unit $\mathrm{F}$ followed by a gradual increase until approximately halfway

231 through Unit H. From this point Si/Ti starts a gradual long-term decline that continues to the top of the sequence and is punctuated by low values in Units I and J. Si/Ti and BSi values are significantly correlated $(\mathrm{r}=0.67, \mathrm{n}=802, p<0.001)$.

\section{Discussion}

235 The Sokli Eemian record has been divided into five main lake phases (L1-L5)

236 based on a number of biotic proxies (Plikk et al., 2016). Additionally, two abrupt 237 climate change events, E1 (the Tunturi Event) and E2, are distinguished 238 (Helmens et al., 2015). Note that L1 corresponds to the initial phase with glacial 239 lake sedimentation and is not included in this study. We first establish what 240 processes control the sediment geochemistry and then place these into context 241 by comparing with previously published proxy data. Finally, we relate changes in 242 our record to key factors controlling lake ontogeny in order to understand why 243 Sokli differs from other boreal sites by becoming increasingly eutrophic.

\section{Identifying the Processes: Interpretation of the PCA and Si/Ti Ratios}

245 The purpose of PCA is to reduce the dimensions of a multivariate data set and

246 explain as much variability as possible with a few components (Reimann et al., 247 2008), thus enabling the identification of variables (i.e., chemical elements in this 248 case) whose behaviour is similar and, thereby, likely controlled by the same 249 process. Three PC were extracted and based on the elemental groupings we are 

able to reconstruct changes in detrital input from outside the SCM (PC1)(Figure

251 2), detrital input from within the SCM (PC2)(Figure 3), and chemical weathering 252 (PC3)(Figure 4). Si/Ti is used as an indicator of lake productivity (Figure 4). PC1 is represented by $\mathrm{Zr}, \mathrm{Ti}, \mathrm{K}, \mathrm{Rb}, \mathrm{Ca}$, and Si (Table 1), which are all part

254 of the crystal structure of common minerals (e.g., silicates, feldspars, micas, titanium oxides, zircon, calcite, apatite) and are therefore transported as detrital material to the lake (Deer et al., 1992). This interpretation is supported by the stratigraphy, where high PC1 scores coincide with visible silt and sand layers (Figure 2). Based on our interpretation of PC2 given below, PC1 is though to be dominated by materials coming from outside the SCM or possibly, till deposited

260 within the SCM, with periods of higher/lower input indicated by

261 positive/negative factors scores. TOC, which is negatively correlated to PC1, is

262 similarly linked to allogenic inputs from the catchment. When TOC is high, the

263 catchment is more productive with more vegetation available to hold materials

264 in place and reduce erosion, which results in negative PC1 scores. rocks of the SCM have relatively high Ca concentrations (6-34\%) while some of

267 the later stages of magmatic carbonatite formation resulted in rocks with up to $2685 \% \mathrm{~S}$, as well as higher than average Fe and Mn concentrations (Vartiainen, 269 1980). The elements associated with PC2 can be transported to the lake as 270 particulate material bound to minerals, in dissolved form, or bound to organic 271 matter (Holmer and Storkholm, 2001). Peaks in PC2 coincide with laminations in 272 the sediments, suggesting a relation to anoxic conditions (Figure 3)(c.f. Plikk et 273 al., 2016). However, even though Fe, S, Mn, and Ca can all precipitate in the water 274 column after being transported in solution to the lake, they experience very 
different behaviour when it comes to redox conditions (Davison, 1993). If changes in redox conditions and the preservation of precipitated $\mathrm{Fe}$ - and $\mathrm{Mn}$ hydroxides and oxyhydroxides were the process driving PC2, it would be expected that Fe and Mn would show opposite patterns, with stronger anoxia giving high Fe and low Mn and vice versa (Wetzel, 2001). Since both elements load positively on PC2 it is unlikely that anoxia is controlling their accumulation in the sediment. Additionally, even if the SCM contains carbonate minerals, the sediment itself contains very low amounts of carbonates $(<0.5 \%$ based on FTIR modelled TIC; Rosén et al., 2010) and hence, Ca is most likely associated with crystalline mineral particles (see below regarding carbonates in association to PC3). Thus increases/decreases in PC2 factor scores describe greater/lesser inputs of non-carbonaceous detrital material originating from SCM rock types rich in mainly $\mathrm{S}$ and $\mathrm{Fe}$, but also $\mathrm{Ca}$ and $\mathrm{Mn}$ (e.g., phoscorites, micas, late stage magmatic carbonatites; Vartiainen, 1980). This said, there have likely been variations in the redox conditions in the lake during the Eemian, and periods preserving laminations most likely had more anoxic conditions as compared to periods without laminations (cf. Plikk et al., 2016).

PC3 is associated with Sr and Ca (Table 1). Strontium is hosted in Ca bearing minerals such as plagioclase, amphibole, pyroxene, and carbonate minerals (Cohen, 2003). It can enter the system detritally or as $\mathrm{Sr}^{2+}$ chemically weathered from the soils and rocks of the catchment. Strontium-rich veins of dolomite carbonatite are only found near the centre of the SCM complex and the surrounding fenites (Lee et al., 2006). The preferential erosion of these veins to produce Sr- and Ca-rich detrital material seems unrealistic and if this did occur, it would be integrated into PC2. This indicates that Sr and Ca are being washed 
into the lake in solution. Once in the water column $\mathrm{Sr}$ and Ca are either co-

301 precipitated and/or absorbed onto the surface of organic matter or Fe-Mn

302 oxides, eventually sinking to the bottom of the lake and being buried in the

303 sediments (Cohen, 2003). Given the fact that Fe and Mn do not load on PC3, it is

304 most likely that soluble $\mathrm{Ca}$ and $\mathrm{Sr}$ are delivered to the sediment through

305 precipitation, although the carbonate concentrations of the sediment are low,

306 and absorption to organic matter. That carbonate precipitation plays a role in $\mathrm{Sr}$

307 and Ca variations and PC3 is verified by the positive correlation between TIC and

308 PC3. Zeng et al. (2013) showed that non-residual Sr has a strong positive

309 correlation with chemical weathering and can be used as a proxy for this process.

310 The pattern of chemical weathering itself is controlled by a number of often

311 related, time-variable factors including physical erosion and the presence of

312 fresh material, temperature, source mineralogy, precipitation, runoff, soil cover,

313 organic matter, and vegetation (White and Blum, 1995; Oliva et al., 2003; Riebe

314 et al., 2004; West et al., 2005; Mavris et al., 2010). As such we stress that PC3 is

315 the integrated expression of several factors related to chemical weathering and

316 the input of soluble Sr and Ca to the lake with increased/decreased chemical

317 weathering signalled by higher/lower factor scores (Figure 4).

318 It should be kept in mind that the PCs model the integrated behaviour of

319 several elements based on the variability observed in the entire profile.

320 Therefore some short term events observed in the PC factor scores may not

321 capture the true behaviour of an element at all times. An inverse correlation

322 should be observed between 1/Sr and PC3 in those samples where Sr is the

323 dominant control on the behaviour of PC3 (Figure 5). This is found to be the case

324 except during periods with higher detrital input (i.e., E1, E2, and sand layers in 
Unit M). Thus, during periods with higher minerogenic flux (positive PC1 scores) we interpret our chemical weathering proxy with caution.

Bearing in mind the fundamental theory of PCA, the individual PC should also not correlate when considering the whole profile. This does not exclude the possibility however, that during a given lake phase the PC cannot show some covariation, as the processes described by the PC may be diminished or enhanced at the same time (Figure 6, Table 3). PC1 and PC2 correlation little (with the exception of the negative correlation in L3) in the different lake phases. This demonstrates that the importance of sources outside the SCM (PC1) and within the SCM (PC2) change over time. This could be a result of changes in (i) vegetation and linked soil erosion; (ii) hydrological pathways; (iii) the size of the lake; and (iv) energy of the transporting waters. While we do not have grain size analyses, PC1 increases during the visibly siltier and sandier layers, which would evoke a coarser grain size for those minerals associated with PC1. In the majority of lake phases PC2 and PC3 are correlated to some degree, which reflects the fact that they are both dominated by sources from within the SCM. PC3 correlates with PC1 and PC2 in E1 and E2. As seen in the plots of 1/Sr vs PC3, the influx of coarse-grained material acts to overprint the chemical weathering signal during these two events.

Silicon can be hosted in both mineral and biological matrices and can play a dual role in lake systems. In contrast, Ti is hosted by mineral phases. Due to this, increases in the $\mathrm{Si} / \mathrm{Ti}$ ratio can either indicate increases in biological productivity (i.e., more biogenic $\mathrm{Si}$ in the sediment) or, as we are dealing with a ratio, decreased input of Ti to the system. As seen in records elsewhere (e.g., Brown et al., 2007; Tanaka et al., 2007; Minyuk et al., 2014), Si/Ti and BSi curves 
are correlated despite the fact that $\mathrm{Si}$ /Ti represents two processes (biological

351 activity and minerogenic input)(Figure 4). In the most obvious cases where the

352 records differ (e.g., 22.20-22.58 m, 21.05-20.98 m, 19.30-19.05 m) we can

353 assume that it is the increased input of Ti and/or a change in the mineral matter

354 character that is driving the mismatch (Chawchai et al., 2016). We recognize that

355 the BSi curve is more representative of within lake biological productivity but

356 compliment this data with $\mathrm{Si} / \mathrm{Ti}$ ratios which are higher resolution.

\section{Lake Development}

$358 \quad$ Lake Phase 2(L2), Early Eemian lake phase (25.0 to $23.45 \mathrm{~m}$ )

359 PC1 and PC2 factor scores suggest that relatively higher minerogenic inputs

360 occur during L2a as compared to L2b (Figure 2 and 3). In that the area was

361 recently deglaciated, this decreasing minerogenic input signals the stabilization

362 of the catchment in the form of soil development (Kylander et al., 2013). This is

363 confirmed by the colonization of the area by open subarctic birch, Pinus, and

364 Juniperus (L2a) and its gradual replacement by interglacial boreal forest with

365 Picea (L2b). The ratio of Arboreal to Non-Arboreal Pollen (AP/NAP) indicates

366 increasing forest cover density from L2a to L2b (Figure 2)(Helmens et al., 2015).

367 Much of L2 is characterized by laminations, reflecting a regularly anoxic

368 hypolimnion and a stably stratified lake (Renberg, 1981). The diatom

369 assemblages present at this time describe short mixing periods and potentially

370 strong seasonality with long, cold winters and short, warm summers (Plikk et al.,

371 2016). Of special note in L2 is the presence of Cyclotella radiosa (Grun.)

372 Lemmermann and Cyclotella michiganiana Skvortz (Figure 3), an oligo-

373 mesotrophic taxa that favours deep, warm waters and stable summer 
stratification (Stoermer, 1993; Wolin, 1996; Whitlock et al., 2012). The diatom

community also indicates that nutrient levels were initially low (L2a) but

gradually rose creating a more eutrophic system (L2b)(Plikk et al., 2016) with

BSi and Si/Ti values similarly showing increasing productivity (Figure 3). Soil development, as evoked by the increases in TOC and AP/NAP (Figure 2), and the leaching of base cations from the unconsolidated glacial materials and the surrounding bedrock after deglaciation could explain the moderate, but still variable behaviour of PC3 during this lake phase (Figure 4); this would help raise lake nutrient levels.

During L2c, minerogenic inputs start to increase again which, given the decrease in AP/NAP, can be linked to a vegetation shift (Figure 2 and 3). The lake flora imply increasingly cold and dynamic conditions and a slight decrease in trophic status (Plikk et al., 2016). Si/Ti values decrease marginally during L2c, likely as a result of the increased minerogenic inputs and cooler conditions (Figure 3). BSi has perhaps a small, but unremarkable, decrease. A very slight decrease in PC3 and chemical weathering occurs which could have contributed to the change in trophic status (Figure 4).

\section{Event 1 (E1), Tunturi Event (23.45 to $22.55 \mathrm{~m})$}

The Tunturi Event is clearly seen in the Sokli record, signalled by the siltier layer at the beginning of E1a. PC1 and PC2 show a double peak just prior to, and after, the boundary to Unit B (Figure 2 and 3). The increase in erosional input is in response to reduced catchment productivity (i.e., TOC), the replacement of the soil protecting mixed boreal forest by an open subarctic birch-dominated woodland (i.e., decrease in AP/NAP) and a temperature drop of $2-4^{\circ} \mathrm{C}$ (Helmens 
et al., 2015). The instability of the soil cover is confirmed by the increase in fossil pollen of Juniperus and Hippophaë rhamnoides, which can cope with such

400 conditions. Aquatic proxy indicators evidence prolonged ice cover as verified by

401 minor increases in Fragilaria (mainly Pseudostaurosira brevistriata (Grun.)

402 Williams \& Round Pseudostaurosira pseudoconstruens Marciniak and Staurosira

403 venter (Grun.) Williams \& Round)(Lotter and Bigler, 2000), lowered lake levels

404 and drier conditions, intense mixing and an earlier breakdown of thermal

405 summer stratification (Plikk et al., 2016). The significant increase in minerogenic

406 input during E1a overprints PC3 and the chemical weathering signal (Figure 4

407 and 5) and affects biological signals either directly by reducing productivity

408 through increased turbidity or indirectly by diluting BSi in the sediment (Figure $4093)$.

PC1 and PC2 factor scores recover by E1b and slowly decrease in E1c

411 indicating recovery of the catchment soils (Figure 2 and 3); a mirror change is

412 observed in TOC and AP/NAP ratios. Increasing biological productivity within

413 the lake is argued by changes in the Si/Ti and BSi data (Figure 3). Laminated

414 sediments return but the stratification, and perhaps the seasonality, is not as

415 extreme as that seen in L2 since diatoms indicating an extended mixing period

416 length are present (e.g., Aulacoseira ambigua (Grun.) Simonsen and

417 Stephanodiscus medius Håkansson)(Figure 3). PC3 is low and stable after E1a

418 with reduced chemical weathering in the catchment, possibly as an effect of the

419 inferred dry conditions of the time (Figure 4)(Plikk et al., 2016).

In E1c laminations disappear indicating there was mixing of bottom

421 waters. Productivity continues to increase during E1c (Figure 3). In examining

422 the elemental data this sub-event appears rather uneventful in terms of detrital 
423 input and chemical weathering. This is curious as the biological data from both

424 within the lake (i.e., diatoms and chironomids) and the catchment (i.e., pollen)

425 show that E1c is a period of minor cooling (Helmens et al., 2015). It is possible

426 that the hydrological conditions did not vary much between E1b and E1c (all

427 affecting the processes described by the elemental data) while the temperature 428 did.

429 Lake Phase 3, Early mid-Eemian lake phase (22.55 to $20.85 \mathrm{~m}$ )

430 The factor scores for PC1 and PC2 generally remain just below zero during L3

431 (Figure 2 and 3). The observed stability is expected considering the return to

432 interglacial conditions, with July temperatures an estimated $3^{\circ} \mathrm{C}$ warmer than

433 present day, and the presence of arboreal-rich vegetation (i.e., increase in

434 AP/NAP) (Helmens et al., 2015). There are again visible laminations in L3

435 indicating oxygen deficient conditions in the hypolimnion. The increased

436 productivity as inferred by $\mathrm{Si} / \mathrm{Ti}$ and BSi may have been enhanced by chemical

437 weathering in the catchment (increase in PC3, Figure 4) and subsequent nutrient

438 addition to the lake, which sees meso-eutrophic and eutrophic species inhabiting

439 the lake (e.g., Stephanodiscus spp. and A. ambigua)(Figure 3). Additionally, these

440 species are likely favoured by an enhanced internal loading of nutrients

441 (especially P) during this phase, as Fe-bound $\mathrm{P}$ that is released and accumulated

442 in the anoxic hypolimnion during the summer stratification is circulated back

443 into the water column during the mixing periods (Bradbury and Dieterich-

444 Rurup, 1993; Wetzel, 2001; Plikk et al., 2016). 
446 During L4 the continued high interglacial temperatures that began in L3 are

447 maintained. It is during L4 that visible laminations disappear, signifying a

448 significant change in the lake system. PC1 and PC2 indicate that minerogenic

449 material input decreases slightly at the start of L4a but thereafter remains rather

450 steady during L4 (Figure 2 and 3). This would imply that the catchment is stable,

451 which is supported by continued relatively high AP/NAP ratio (Helmens et al., 452 2015).

In L4 the long-term lake infilling that started after deglaciation appears to

454 cross a key depth threshold. There are several indications of lower lake levels,

455 increased mixing, and reduced bottom water anoxia. For example, there is

456 change from weak laminations (Unit F) to no visible laminations (Unit G). The

457 aquatic assemblages increase in benthic diatoms and littoral green algae evoking

458 lake shallowing (Plikk et al., 2016), e.g. Staurosira construens v. binodis (Ehrenb.)

459 Hamilton that prefers shallow, macrophyte-rich, eutrophic lakes (Figure

460 2)(Bradbury and Winter, 1976). The increase in A. ambigua, a species often

461 found in shallow lakes and near-shore areas of deep lakes and which requires

462 high levels of turbulence and light to prosper (Bradbury and Dieterich-Rurup,

463 1993), also validates the idea that the lake in L4 is shallow and well mixed

464 (Figure 3). This lake phase also sees the highest values in the productivity

465 indicators $\mathrm{Si} / \mathrm{Ti}$ and $\mathrm{BSi}$, particularly in L4a.

466 L4 is also distinct in that PC3 shows gradually increasing positive values

467 over several meters of accumulation (Figure 4). At this time acidophilous

468 diatoms such as Aulacoseira alpigena (Grun.) Krammer and Tabellaria flocculosa

469 (Roth.) Kütz. appear in low amounts (Van Dam et al., 1994), indicating a slight 
decrease in the $\mathrm{pH}$ of the lake waters (Figure 4). The on-going development of

471 soils would increase the production of SOM and DOC, promoting acid conditions

472 (Pienitz et al., 1999; Engstrom et al., 2000; Fritz et al., 2004). Within the

473 catchment there is an increase in coniferous tree species like Picea in the mixed

474 boreal forest present; this leads to increased DOC transport from the catchment

475 soils as compared to deciduous vegetation (Van Nevel, 2013). The increase in

476 pollen of several floating leaved macrophytes such as Nuphar spp. and

477 unidentified Nymphaceae, especially in L4b, attests to decreasing transparency

478 associated with increasing DOC in the lake (Plikk et al., 2016). The increasing

479 chemical weathering however, appears to offset significant acidification as there

480 is continued presence of species found in near-shore areas of eutrophic lakes

481 (e.g., S. parvus, Fragilaria capucina v. mesolepta (Rabenh.) Rabenh. and

482 Cyclostephanos invisitatus Theriot, Stoermer \& Håkansson comb. Nov.)(Plikk et 483 al., 2016).

Event 2 (E2)(17.43 to $17.05 \mathrm{~m})$

485 E2 clearly mimics E1 and evidences another significant climate perturbation 486 with cool conditions (Helmens et al., 2015) and a sharp influx of minerogenic 487 material early in E2 (i.e., PC1 and PC3 increase) (Figure 2 and 4). Decreases in 488 TOC (Figure 2), Si/Ti, and BSi (Figure 3) may signal a decrease in biological 489 productivity in both the lake and the catchment but dilution by minerogenic 490 influx is also again possible. The main difference between E2 and E1 lays in the 491 fact that during the latter event the lake is much shallower due to progressive 492 infilling. The increase in diatom species that thrive in subaerial conditions and 493 rivers as well as an increase in Sphagnum spores and unidentified terrestrial 
494 plant remains suggests decreased lake levels (Figure 2)( Väliranta, 2006; Plikk et 495 al., 2016).

496 After this seemingly abrupt event the system seems to recover again with

497 PC1, PC3, TOC, BSi, and Si/Ti going back to pre-event levels indicating more

498 productive conditions and moderate chemical weathering (Figure 2, 3, and 4).

499 The sediment at this time is characterized by light yellow spots which might be

500 related to subaerial exposure or bottom freezing, and planktonic diatoms almost

501 completely disappear (Plikk et al., 2016).

$502 \quad$ Lake Phase $5(17.05-16.00 \mathrm{~m})$

503 Early in this lake phase, PC1 and PC2 indicate that minerogenic inputs are rather

504 constant in L5a despite low AP/NAP ratios (Figure 2 and 3). Likewise, PC3 is low

505 at this time (Figure 4). This may be related to infilling and the expansion of

506 Sphagnum in the area, which acts to filter incoming sediment when lake levels

507 are low. TOC levels also increase suggesting a vegetated catchment. While

508 diatoms indicate increased lake levels compared to E2, the presence of diatoms

509 common to acidic (e.g., A. alpigena) and shallow telmatic conditions (e.g., $S$.

510 construens v. binodis) corroborates this continued infilling (Plikk et al., 2016)

511 (Figure 2 and 4). Productivity is initially high but starts to decline leading up to

512 the start of L5b (Figure 3). In these conditions there appears to be available

513 oxygen and high mixing, as shown by a peak in A. ambigua.

$514 \quad$ In L5b the stratigraphy, PC1, PC2, and PC3 have a distinct pattern

515 representing an unstable environment with the in-wash of silt and sand in flood

516 type events (Figure 2). The general instability of L5b is verified by the increased

517 presence of the diatoms S. venter and S. pinnata, which can tolerate rapidly 
changing environments and are often found in shallow waters with sandy

519 substrates (Haworth, 1976; Jones and Birks, 2004). Sphagnum grows in

520 importance as infilling proceeds (Figure 2). The diatom flora move towards

521 those species found in subarctic/arctic lakes (e.g., Staurosirella lapponica (Grun.)

522 Williams \& Round, S. venter, S. pinnata) and Betula becomes more abundant in

523 the pollen data, indicating a move towards cool conditions (Plikk et al., 2016).

\section{$524 \quad$ Postglacial Boreal Lake Ontogeny}

525 Lakes in northern boreal regions are commonly shallow, extremely dilute, clear,

526 and oligotrophic (e.g., for Fennoscandinavia and the Kola Peninsula; Korhola and

527 Weckström, 2004). Paleoclimate records reconstructed from late glacial and

528 Holocene lake sediments in these regions integrate both climate as well as

529 natural lake ontogeny, which often see the long-term postglacial

530 oligotrophication of the lake (Ford, 1990; Pienitz et al., 1999; Engstrom et al.,

531 2000; Fritz et al., 2004; Boyle, 2007; Fritz and Anderson, 2013; Law et al., 2015).

532 As is common in the early phase of postglacial lake evolution elsewhere (e.g.,

533 Korhola and Weckström, 2004; Kylander et al., 2011), Sokli sees an initial period

534 of high minerogenic input that is curbed by the development of catchment soils

535 and colonizing vegetation. In L2a oligo-mesotrophic diatom species are already

536 present and, with the exception of during E1 and E2, Sokli follows a trajectory

537 towards meso-eutrophic conditions, a productive lake, and gradual infilling of

538 the basin. Clearly, Sokli follows a path of long-term eutrophication rather than

539 oligotrophication.

A number of abiotic and biotic processes are thought to drive postglacial

541 oligotrophication of lakes. The high alkalinity and productivity observed within 

the first few millennia after deglaciation are linked to (i) primary succession and species immigration and (ii) leaching of cations from soils and bedrock (Fritz and

544 Anderson, 2013). At Sokli there are shrubs (i.e., low AP/NAP), Betula, and Alnus

545 present after deglaciation followed by the arrival of Pinus and Picea and an

546 increasing proportion of trees. This vegetation succession is rather typical of

547 postglacial landscapes in Fennoscandinavia (Donner, 1995) and does not seem to

548 explain why Sokli becomes increasingly eutrophic over time. The early presence

549 of Alnus at Sokli could be important given its role in $\mathrm{N}$ fixation and supply of

550 nutrients to the catchment (Fritz et al., 2004; Engstrom and Fritz, 2006). Alnus is

551 continuously present throughout the Eemian record at Sokli but this should be

552 interpreted with caution, given the fact that Alnus is an abundant pollen

553 producer (Bradshaw, 1981) which can be overrepresented in pollen data when

554 locally present (Tinsley and Smith, 1974). Catchment and soil weathering,

555 particularly within the base cation- and P-rich SCM (Talvitie et al., 1981), would

556 maintain both the alkalinity and nutrient supply to the lake, rather than it being

557 exhausted as seen in typical granitic and gneissic landscapes (Fritz and

558 Anderson, 2013). Several studies suggest that this climate independent, abiotic

559 edaphic process is a more important control on lake ontogeny than biological

560 processes (Boyle, 2007; Law et al., 2015) and the lake evolution at Sokli would

561 seem to lend support to this. The vegetative succession and the (iii)

562 accumulation of SOM and increased DOC input was also interrupted at Sokli

563 during E1 and E2 where conditions are glacial-like with high minerogenic inputs,

564 low temperature, increased Betula, Juniper, and shrubs. This could potentially

565 alter the trajectory of the lake with the external climate signals overriding lake

566 ontogeny processes. Finally, (iv) hardpan formation and the expansion of 
wetlands can inhibit leaching of base cations and the maintenance of alkalinity

568 (Engstrom et al., 2000; Fritz and Anderson, 2013). While we are not able to say

569 much in regards to ground water input, Sphagnum percentages indicate the

570 development of wetlands only late in the Sokli sequence.

\section{Conclusions}

572 The long-term oligotrophication normally seen in postglacial boreal lakes is not

573 observed at Sokli and reasons for this were explored using the elemental

574 geochemistry of the lake sediments. Lake sediment geochemistry is controlled by

575 a number of integrated factors including the geological setting, lake and

576 catchment development, and climate variability. Three main processes

577 controlling the sediment geochemistry at Sokli were identified: (i) detrital input

578 from sources dominantly beyond the SCM; (ii) detrital input from sources

579 dominantly within the SCM; and (iii) chemical weathering. In general, the lake

580 evolution was characterized by stable minerogenic inputs with varying

581 importance of sources from both outside and inside the SCM over time. These

582 inputs contributed to the long-term infilling of the lake. Chemical weathering

583 increased over the span of the Eemian record at Sokli. The SCM provided an

584 abundant and continual supply of base cations and nutrients, which helped to

585 maintain a relatively alkaline and increasingly eutrophic lake. We note the

586 highest levels of chemical weathering occurred during L3 and L4 when

587 temperatures were higher than present day; there was increased presence of

588 acidic Picea; and slightly higher catchment productivity (TOC). Trends in the

589 processes described above were however, interrupted during both E1 and E2,

590 which saw the influx of significant amounts of detrital material, overwhelming 

the geochemical signals. At Sokli it appears that the forcing from abiotic edaphic process and climate override the typical postglacial oligotrophication normally seen in boreal lakes.

\section{Acknowledgements}

We gratefully acknowledge the Geological Survey of Finland for field and coring assistance. This study was funded by the Swedish Nuclear Fuel and Waste Management Company (SKB) and the Bolin Centre for Climate Research at Stockholm University. Additional funding was provided by Stiftelsen Längmanska kulturfonden, Academy of Finland (project no. 278692) and the Finnish Cultural Foundation. MEK dedicates this article to her father and thanks all the staff at the Virginia Commonwealth University who helped him through a successful open-heart surgery during the resubmission of this article.

\section{References}

Alexanderson, H., Eskola, K.O., Helmens, K.F., 2008. Optical dating of a late Quaternary sediment sequence from Sokli, northern Finland. Geochronometria 32: 51-59.

Battarbee, R.W., Jones, V.J., Flower, R.J., Cameron, N.G., Bennion, H., Carvalho, L., Juggins, S., 2003. Diatoms, in: Smol, J.P., Birks, H.J.B., Last, W.M. (Eds.), Tracking Environmental Change Using Lake Sediments: Terrestrial, Alagal and Silicious Inidcators, Developments in Paleoenvironmental Research. Kluwer Academic Publishers, Dordrecht, pp. 155-202.

Bauch, H.A., Kandiano, E.S., Helmke, J., Andersen, N., Rosell-Mele, A., Erlenkeuser, H., 2011. Climatic bisection of the last interglacial warm period in the Polar North Atlantic. Quaternary Science Reviews 30: 1813-1818.

Bińka, K., Nitychoruk, J., Dzierżek, J., 2011. Climate stability during the Eemian new pollen evidence from the Nidzica site, northern Poland. Boreas 40: 342350.

Björck, S., Noe-Nygaard, N., Wolin, J., Houmark-Nielsen, M., Jørgen Hansen, H., Snowball, I., 2000. Eemian Lake development, hydrology and climate: a multi-stratigraphic study of the Hollerup site in Denmark. Quaternary Science Reviews 19: 509-536.

Boyle, J.F., 2007. Loss of apatite caused irreversible early-Holocene lake 
acidification. The Holocene 17:543-547.

Bradbury, J.P., Dieterich-Rurup, K.V., 1993. Holocene diatom paleolimnology of Elk Lake, Minnesota. In: Bradbury, J.P., Dean, W.E. (Eds.), Elk Lake, Minnesota: Evidence for Rapid Climate Change in the North-central United States. Geological Society of America Special Paper, Boulder, Colorado, pp. 215-237.

Bradbury, J.P., Winter, T.C., 1976. Areal Distribution and Stratigraphy of Diatoms in the Sediments of Lake Sallie, Minnesota. Ecology 57, 1005-1014.

Bradshaw, R.H.W., 1981. Modern pollen-representation factors for woods in south-east England. Journal of Ecology 69: 45-70.

Brown, E.T., Johnson, T.C., Scholz, C.A., Cohen, A.S., King, J.W., 2007. Abrupt change in tropical African climate linked to the bipolar seesaw over the past 55,000 years. Geophysical Research Letters 34. doi:10.1029/2007GL031240

Chawchai, S., Kylander, M.E., Chabangborn, A., 2016. Testing commonly used Xray fluorescence core scanning-based proxies for organic-rich lake sediments and peat. Boreas 45:180-189.

Cheddadi, R., Mamakowa, K., Guiot, J., de Beaulieu, J.-L., Reille, M., Andrieu, V., Granoszewski, W., Peyron, O., 1998. Was the climate of the Eemian stable? A quantitative climate reconstruction from seven European pollen records. Palaeogeography, Palaeoclimatology and Palaeoecology 143: 73-85.

Cohen, A.S., 2003. Paleolimnology: The History and Evolution of Lake Systems. Oxford University Press, Oxford.

Cortijo, E., Duplessy, J.C., Labeyrie, L., Leclaire, H., Duprat, J., Van Wearing, T., 1994. Eemian cooling in the Norwegian Sea and North Atlantic ocean preceding continental ice-sheet growth. Nature 372: 446-449.

Davison W, 1993. Iron and Manganese in Lakes. Earth-Science Reviews 34: 119163.

Deer, W.A., Howie, R.A., Zussman, J., 1992. An introduction to the rock-forming minerals. Harlow: Longman Scientific \& Technical.

Donner, J. (1995) The Quaternary History of Scandinavia. Cambridge University Press, Cambridge, UK.

Drebs, A., Nordlund, A., Karlsson, P., Helminen, J., Rissanen, P., 2002. Climatological statistics of Finland 1971-2000. Finish Meterological Institute, Helsinki.

Engstrom, D.R., Fritz, S.C., 2006. Coupling between primary terrestrial succession an the trophic development of lakes at Glacier Bay, Alaska. Journal of Paleolimnology 35: 873-880.

Engstrom, D.R., Fritz, S.C., Almendinger, J.E., Juggins, S., 2000. Chemical and biological trends during lake evolution in recently deglaciated terrain. Nature 408: 161-166.

Eriksson, L., Johansson, E., Kettaneh-Wodl, N., Wold, S., 1999. Introduction to Multi- and Mega-Variate Data Anlysis using Projection Methods (PCA \& PLS). Umetrics AB, Umeå.

Ford, M.S.J., 1990. A 10,000-year history of natural ecosystem acidification. Ecological Monographs 60: 57-89.

Fritz, S.C., Anderson, N.J., 2013. The relative influences of climate and catchment processes on Holocene lake development in glaciated regions. Journal of Paleolimnology 49: 349-362.

Fritz, S.C., Engstrom, D.R., Juggins, S., 2004. Patterns of early lake evolution in 
boreal landscapes: a comparison of stratigraphic inferences with a modern chronosequence in Glacier Bay, Alaska. The Holocene 14: 828-840.

Fronval, T., Jansen, E., 1996. Rapid changes in ocean circulation and heat flux in the Nordic seas during the Last Interglacial period. Nature 383: 745-844.

Galaasen, E.V., Ninnemann, U.S., Irval, N., Kleiven, H.F., Rosenthal, Y., Kissel, C., Hodell, D.A., 2014. Rapid Reductions in North Atlantic Deep Water During the Peak of the Last Interglacial Period. Science 343: 1129-1132.

Haworth, E.Y., 1976. Two late-glacial (late Devensian) diatom assemblage profiles from northern Scotland. New Phytologist 77: 227-256.

Helmens, K.F., Bos, J.A.A., Engels, S., Van Meerbeeck, C.J., Bohncke, S.J.P., Renssen, H., Heiri, O., Brooks, S.J., Seppä, H., Birks, H.J.B., Wohlfarth, B., 2007. Presentday temperatures in northern Scandinavia during the last glaciation. Geology 35: 987-990.

Helmens, K.F., Räsänen, M.E., Johansson, P.W., 2000. The last interglacial-glacial cycle in NE Fennoscandia: a nearly continuous record from Sokli (Finnish Lapland). Quaternary Science Reviews 19: 1605-1623.

Helmens, K.F., Salonen, J.S., Plikk, A., Engels, S., Väliranta, M., Kylander, M., Brendryen, J., Renssen, H., 2015. Major cooling intersecting peak Eemian Interglacial warmth in northern Europe. Quaternary Science Reviews 122: 293-299.

Holmer, M., Storkholm, P., 2001. Sulphate reduction and sulphur cycling in lake sediments: a review. Freshwater Biology 46: 431-451.

Ilvonen, E., 1973. Eem - kerrostuma savukosken soklilla. Julkaisija: Suomen Geologinen Seura 25: 81-84.

Irvall, N., Ninnemann, U.S., Galaasen, E.V., Rosenthal, Y., Kroon, D., Oppo, D.W., Kleiven, H.F., Darling, K.F., Kissel, C., 2012. Rapid switches in subpolar North Atlantic hydrography and climate during the Last Interglacial (MIS 5e). Paleoceanography 27: PA2207.

Jones, V., Birks, H., 2004. Lake-sediment records of recent environmental change on Svalbard: results of diatom analysis. Journal of Paleolimnology 31: 445466.

Jones, B.F., Bowser, C.J., 1978. The mineralogy and related chemistry of lake sediments. In Lerman, A. (Ed.), Lakes: Chemistry, Geology, Physics. Springer New York, pp. 179-235.

Jørgensen, B.,B., 1990. The sulfur cycle of freshwater sediments: Role of thiosulfate. Limnology and Oceanography 35: 1329-1342.

Korhola, A., Weckström, J., 2004. Paleolimnological studies in Arctic Fennoscandinavia and the Kola Peninsula (Russia). In Pienitz, R., Douglas, M.S.V., Smol, J. (Eds). Developments in Paleoenvironmental Research, Springer Academic, pp. 381-418.

Kühl, N., Litt, T., Schölzel, C., Hense, A., 2007. Eemian and Early Weichselian temperature and precipitation variability in northern Germany. Quaternary Science Reviews 26: 3311-3317.

Kylander, M.E., Ampel, L., Wohlfarth, B., 2011. High-resolution X-ray fluorescence core scanning analysis of Les Echets (France) sedimentary sequence: new insights from chemical proxies. Journal of Quaternary Science 26: 109-117.

Kylander, M.E., Klaminder, J., Wohlfarth, B., Löwemark, L., 2013. Geochemical responses to paleoclimatic changes in southern Sweden since the late glacial: the Hässeldala Port lake sediment record. Journal of Paleolimnology 50: 57- 
70.

Law, A.C., Anderson, N.J., McGowan, S., 2015. Spatial and temporal variability of lake ontogeny in south-western Greenland. Quaternary Science Reviews 126: 1-16.

Lee, M.J., Lee, J.I., Garcia, D., Moutte, J., Williams, C.T., Wall, F., Kim, Y., 2006. Pyrochlore chemistry from the Sokli phoscorite-carbonatite complex, Finland: Implications for the genesis of phoscorite and carbonatite association. Geochemical Journal 40: 1-13.

Lee, M.J., Lee, J.I., Moutte, J., 2005. Compositional variation of Fe-Ti oxides from the Sokli complex, northeastern Finland. Geosciences Journal 9: 1-13.

Ljung, K., Holmgren, S., Kylander, M., Sjolte, J., Van der Putten, N., Kageyama, M., Porter, C.T., Björck, S., 2015. The last termination in the central South Atlantic. Quaternary Science Reviews 123: 193-214.

Lotter, A.F., Bigler, C., 2000. Do diatoms in the Swiss Alps reflect the length of icecover? Aquatic Sciences 62: 125-141.

Mavris, C., Egli, M., Plötze, M., Blum, J.D., Mirabella, A., Giaccai, D., Haeberli, W., 2010. Initial stages of weathering and soil formation in the Morteratsch proglacial area (Upper Engadine, Switzerland). Geoderma 155: 359-371.

Minyuk, P.S., Borkhodoev, V.Y., Wennrich, V., 2014. Inorganic geochemistry data from Lake El'gygytgyn sediments: marine isotope stages 6-11. Climate of the Past 10: 467-485.

Oliva, P., Viers, J., Dupré, B., 2003. Chemical weathering in granitic environments. Chemical Geology 202: 225-256.

Pienitz, R., Smol, J.P., MacDonald, G.M., 1999. Paleolimnological Reconstruction of Holocene Climatic Trends from Two Boreal Treeline Lakes, Northwest Territories, Canada. Arctic, Antarctic, and Alpine Research 31: 82-93.

Plikk, A., Helmens, K.F., Fernandez-Fernandez, M., Kylander, M.E., Löwemark, L., Risberg, J., Salonen, J.S., Väliranta, M., Weckström, J., 2016. Development of an Eemian (MIS 5e) Interglacial palaeolake at Sokli (N Finland) inferred using multiple proxies. Palaeogeography, Palaeoclimatology, Palaeoecology 463: 11-26.

Reimann, C., Filzmoser, P., Garret, R., Dutter, R., 2008. Statistical data analysis explained: Applied environmental statistics. John Wiley \& Sons Ltd.

Renberg, I., 1981. Formation, structure and visual appearance of iron-rich, varved lake sediments. Proceedings - International Association of Theoretical and Applied Limnology 21: 94-101.

Riebe, C.S., Kirchner, J.W., Finkel, R.C., 2004. Erosional and climatic effects on long-term chemical weathering rates in granitic landscapes spanning diverse climate regimes. Earth and Planetary Science Letters 224: 547-562.

Rioual, P., Andrieu-Ponel, V., de Beaulieu, J.L., Reille, M., Svobodova, H., Battarbee, R.W., 2007. Diatom responses to limnological and climatic changes at Ribains Maar (French Massif Central) during the Eemian and Early Würm. Quaternary Science Reviews 26: 1557-1609.

Rosén, P., Vogel, H., Cunningham, L., Reuss, N., Conley, D., Persson, P., 2010. Fourier transform infrared spectroscopy, a new method for rapid determination of total organic and inorganic carbon and biogenic silica concentration in lake sediments. Journal of Paleolimnology 43: 247-259.

Seidenkrantz, M.S., Kristensen, P., Knudsen, K.L., 1995. Marine evidence for climatic instability during the last interglacial in shelf records from 
northwest Europe. Journal of Quaternary Science 10: 77-82.

Shchukarev, A., Gälman, V., Rydberg, J., Sjöberg, S., Renberg, I., 2008. Speciation of iron and sulphur in seasonal layers of varved lake sediment: an XPS study. Surface and Interface Analysis 40: 354-357.

Stoermer, E. 1993. Evaluating diatom succession: some pecularities of the Great Lakes case. Journal of Paleolimnology 8: 71-83.

Talvitie, J., Lehmuspelto, P., Vuotovesi, T., 1981. Airborne Thermal Surveying of the Ground in Sokli, Finland. Geological Survey of Finland.

Tanaka, K., Akagawa, F., Yamamoto, K., Tani, Y., Kawabe, I., Kawai, T., 2007. Rare earth element geochemistry of Lake Baikal sediment: its implication for geochemical response to climate change during the Last Glacial/Interglacial transition. Quaternary Science Reviews 26: 1362-1368.

Tinsley, H., Smith, R.T., 1974. Surface pollen studies across a woodland/heath transition and their application to the interpretation of pollen diagrams. New Phytologist 73: 547-565.

Van Dam, H., Mertens, A., Sinkeldam, J., 1994. A coded checklist and ecological indicator values of freshwater diatoms from the Netherlands. Netherlands Journal of Aquatic Ecology 28: 117-133.

Van Nevel, L., Mertens, J., De Schrijver, A., Baeten, L., De Neve, S., Tack, F.M., Meers, E., Verheyen, K., 2013. Forest floor leachate fluxes under six different tree species on a metal contaminated site. Science of the Total Environment 447: 99-107.

Vartiainen, H., 1980. The Petrography, mineralogy and petrochemistry of the Sokli carbonatite massif, northern Finland. Geological Survey of Finland.

Väliranta, M., 2006. Terrestrial plant macrofossil records; possible indicators of past lake-level fluctuations in north-eastern European Russia and Finnish Lapland. Acta Palaeobotanica 46: 235-243.

West, A., Galy, A., Bickle, M., 2005. Tectonic and climatic controls on silicate weathering. Earth and Planetary Science Letters 235: 211-228.

Wetzel, R.G., 2001. Limnology. Academic Press.

White, A.F., Blum, A.E., 1995. Effects of climate on chemical weathering in watersheds. Geochimica et Cosmochimica Acta 59: 1729-1747.

Whitehead, D.R., Charles, D.F., Jackson, S.T., Smol, J.P., Engstrom, D.R., 1989. The developmental history of Adirondack (NY) lakes. Journal of Paleolimnology 2:185-206.

Whitlock, C., Dean, W., Fritz, S., Stevens, L., Stone, J., Power, M., Rosenbaum, J., Pierce, K. and Bracht-Flyr, B. 2012. Holocene seasonal variability inferred from multiple proxy records from Crevice Lake, Yellowstone National Park, USA. Palaeogeography, Palaeoclimatology, Palaeoecology 331: 90-103.

Wittkop, C., Teranes, J., Lubenow, B., Dean, W.E., 2014 Carbon- and oxygen-stable isotopic signatures of methanogenesis, temperature, and water column stratification in Holocene siderite varves. Chemical Geology 389: 153-166.

Wolin, J. 1996. Late Holocene lake-level and lake development signals in Lower Herring Lake, Michigan. Journal of Paleolimnology 15: 19-45.

Zeng, Y., Chen, J., Xiao, J., Qi, L., 2013. Non-residual Sr of the sediments in Daihai Lake as a good indicator of chemical weathering. Quaternary Research 79: 284-291. 
Table 1. Variance explained by each factor

\begin{tabular}{l|ccc}
\hline Factor & Variance & \% & Cumulative \% \\
& & & \\
\hline \hline 1 & 4,19 & 41,91 & 41,91 \\
2 & 2,61 & 26,15 & 68,06 \\
3 & 1,33 & 13,30 & 81,37 \\
\hline
\end{tabular}

819 Table 2. Rotated factor loadings. Shaded data are significant at the $\alpha 0.05$ level.

\begin{tabular}{l|ccc}
\hline Element & Factor $\mathbf{1}$ & Factor 2 & Factor 3 \\
\hline \hline $\mathrm{K}$ & 0,94 & 0,25 & 0,00 \\
$\mathrm{Ti}$ & 0,94 & 0,26 & 0,03 \\
$\mathrm{Rb}$ & 0,93 & 0,17 & $-0,09$ \\
$\mathrm{Zr}$ & 0,83 & $-0,28$ & 0,19 \\
$\mathrm{Si}$ & 0,71 & 0,16 & 0,05 \\
$\mathrm{Fe}$ & 0,28 & 0,80 & $-0,37$ \\
$\mathrm{~S}$ & 0,09 & 0,93 & 0,06 \\
$\mathrm{Mn}$ & 0,02 & 0,63 & $-0,29$ \\
$\mathrm{Ca}$ & 0,54 & 0,65 & 0,43 \\
$\mathrm{Sr}$ & 0,07 & $-0,21$ & 0,93 \\
\hline
\end{tabular}

820

821 Table 3. Correlation coefficients between the PC during different lake phases and events

\begin{tabular}{l|l|r|r}
\hline Lake Phase/Event & & \multicolumn{1}{|c}{ PC2 } & \multicolumn{1}{c}{ PC3 } \\
\hline \hline L5 & PC1 & 0.44 & 0.03 \\
& PC2 & & 0.68 \\
\hline E2 & PC1 & 0.64 & 0.81 \\
& PC2 & & 0.80 \\
\hline L4 & PC1 & 0.39 & -0.53 \\
& PC2 & & 0.74 \\
\hline L3 & PC1 & -0.67 & -0.24 \\
& PC2 & & 0.67 \\
\hline E1 & PC1 & 0.23 & 0.62 \\
& PC2 & & 0.68 \\
\hline L2 & PC1 & -0.24 & -0.50 \\
& PC2 & & 0.15 \\
\hline
\end{tabular}

822 
824 1. Location of the study site in northern Finland (A). The Sokli Eemian paleolake

825 sits in the Sokli Carbonatite Massif (SCM), a carbonatite-alkaline complex

826 surrounded by crystalline Precambrian Shield. The work presented here is 827 from Borehole 2 (B).

828 2. Depth profiles of PC1, TOC, S. construens v. binodis, AP/NAP ratios, and 829 Sphagnum pollen percentages. PC1 is representative of minerogenic inputs 830 from sources outside the SCM while TOC tracks catchment productivity. $S$. 831 construens $\mathrm{v}$. binodis is used here as an indicator of lake infilling while AP/NAP tells us about the relative importance of trees versus other species

834 of Sphagnum is also linked to infilling of the lake. The bracketing glaciofluvial 835 sands and gravel (28.5 and $25 \mathrm{~m}$ ) and fluvial sands (16 to $13 \mathrm{~m}$ ) have been 836 dated to >ca. 95 and $110 \mathrm{ka}$ and <ca. 150-180 ka, respectively (Helmens et al., 837 2000; 2007; Alexanderson et al., 2008).

838 3. Depth profiles of PC2, C. radiosa, C. michiganiana, A. ambigua, S. medius, Si/Ti, 839 and BSi. PC2 represents inputs from S, Fe, Mn, and Ca-rich sources within the 840 SCM. Both C. radiosa and C. michiganiana are species that favour deep, warm 841 waters with stable summer stratification. A. ambigua and S. medius require an 842 extended mixing period length and eutrophic and productive conditions. Si/Ti 843 and BSi are indicators of in-lake productivity.

844 4. Depth profiles of PC3, T. flocculosa, A. alpigena, Picea pollen percentages, and $845 \quad$ Picea stomata. PC3 represents the integrated signal of those processes 846 controlling chemical weathering. Both T. flocculosa and A. alpigena are 847 acidophilic species and are used as indicators of $\mathrm{pH}$ trends in the lake. Picea 
848 pollen and stomata are used to highlight the increase presence of these

849 acidifying species.

850 5. Depth profiles of PC1, PC2, and PC3 show that the PC co-vary during certain 851 phases of lake development.

852 6. Plot of $1 / \mathrm{Sr}$ vs. PC3 where a negative correlation indicates that Sr is the main 853 control on PC3 variability.

\section{Supplementary Information}

855 Raw data elemental profiles by depth given in peak areas. 
Kylander et al.-Figure 1
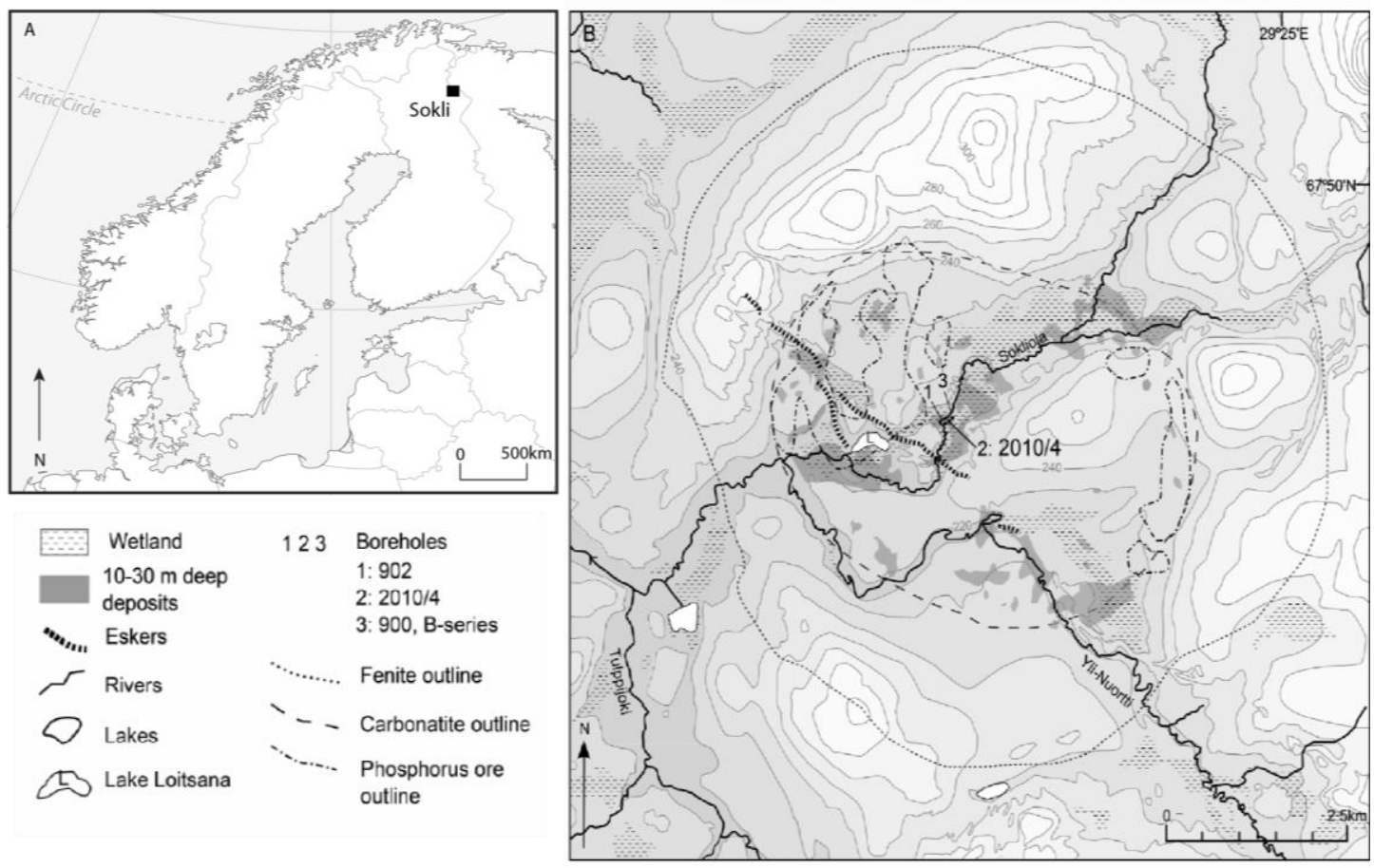

856

857 
Kylander et al.-Figure 2

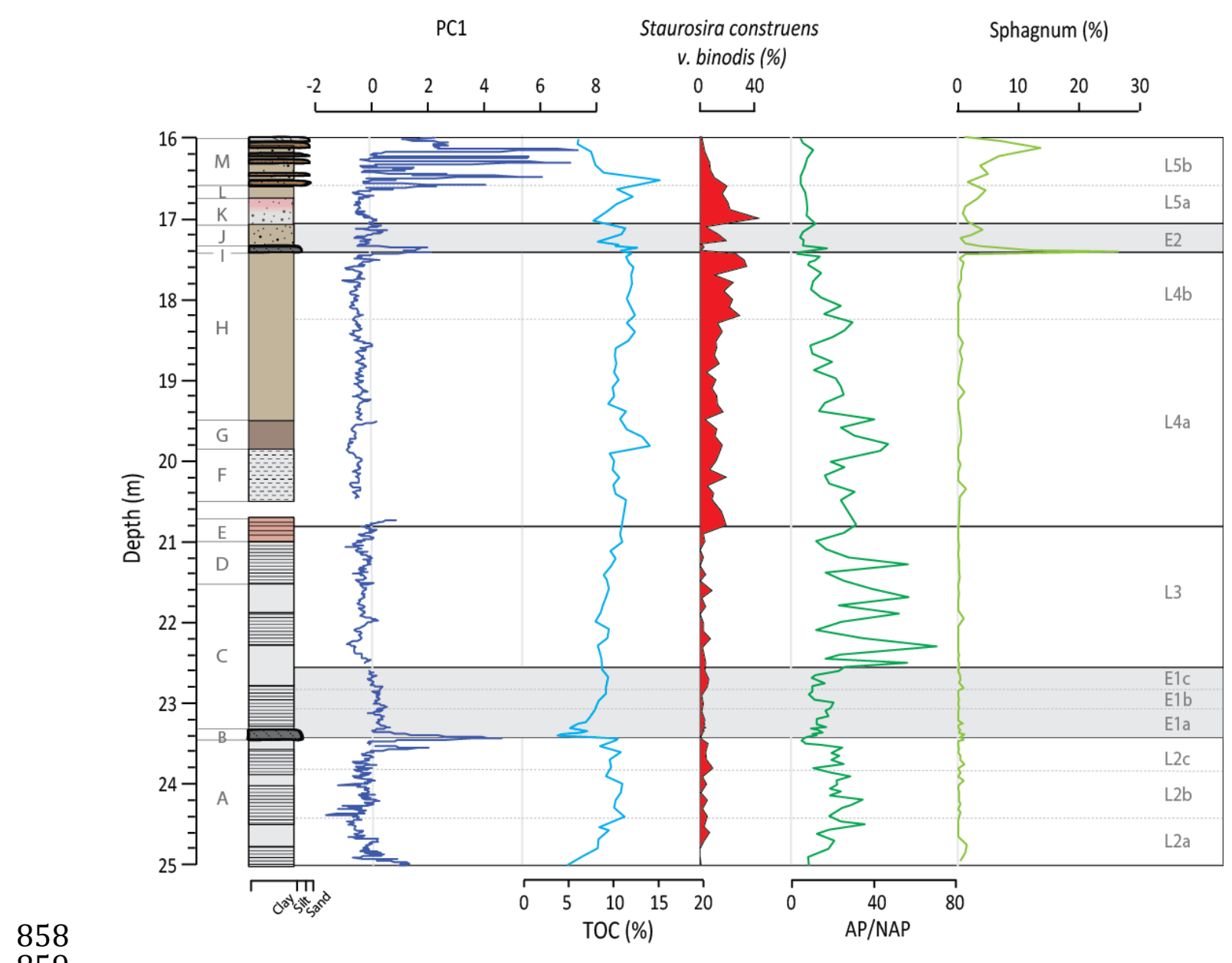

859 
Kylander et al.-Figure 3

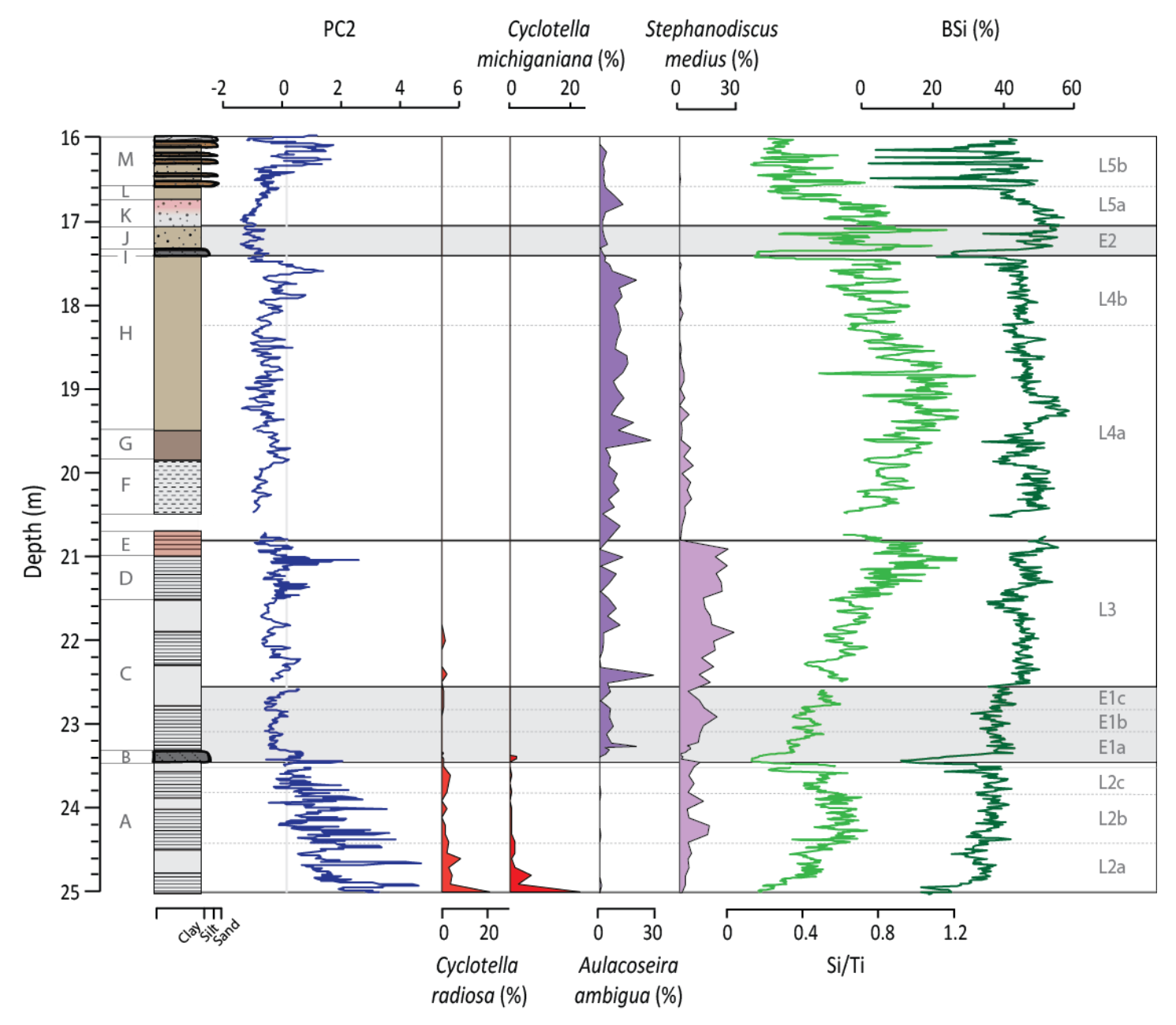

860

861 
Kylander et al.-Figure 4

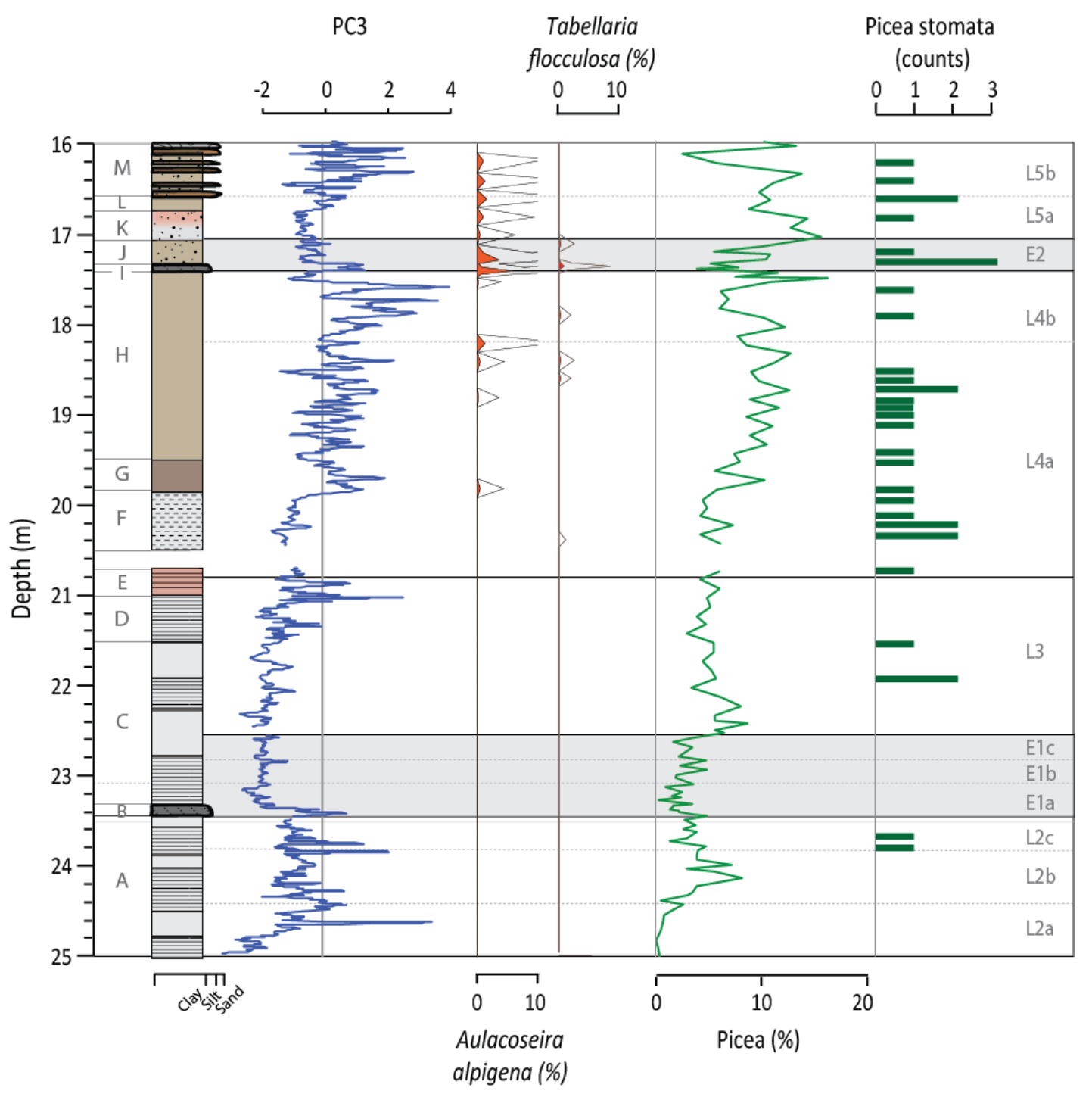

862

863 
Kylander et al.-Figure 5

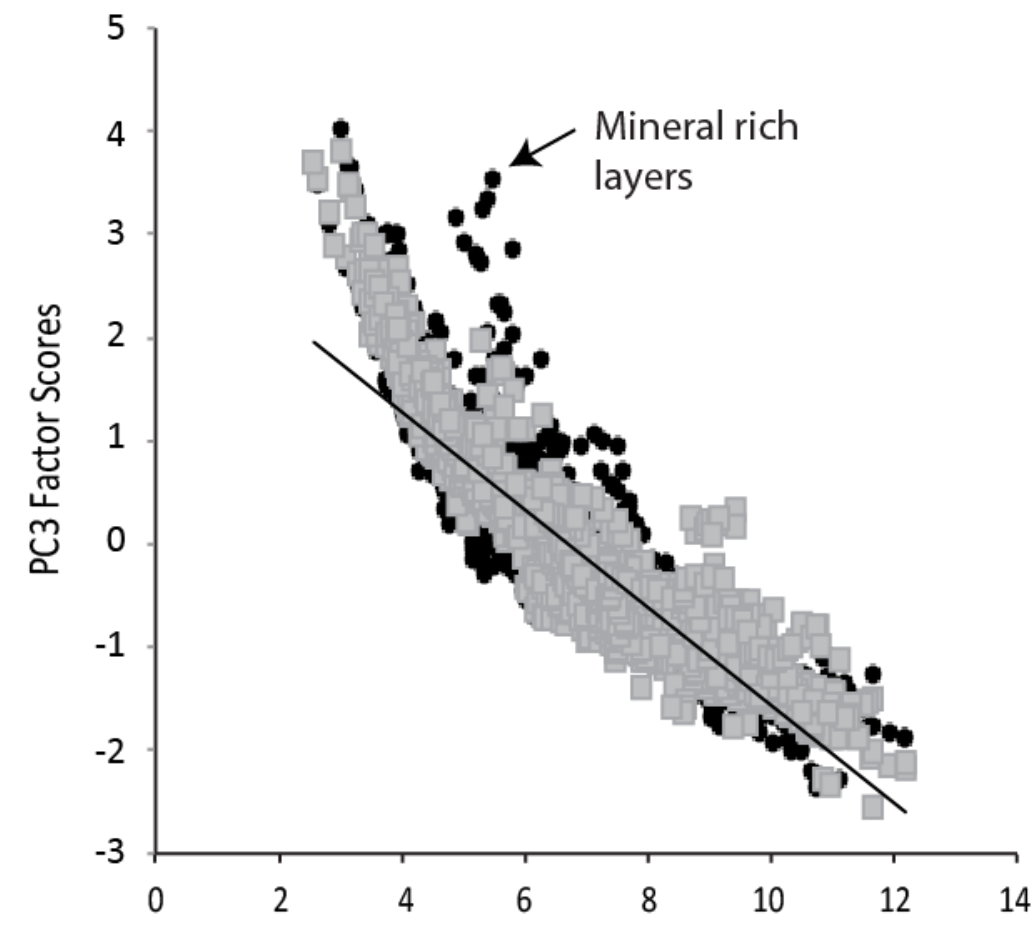

864

$1 / \mathrm{Sr}$ 
Kylander et al.-Figure 6

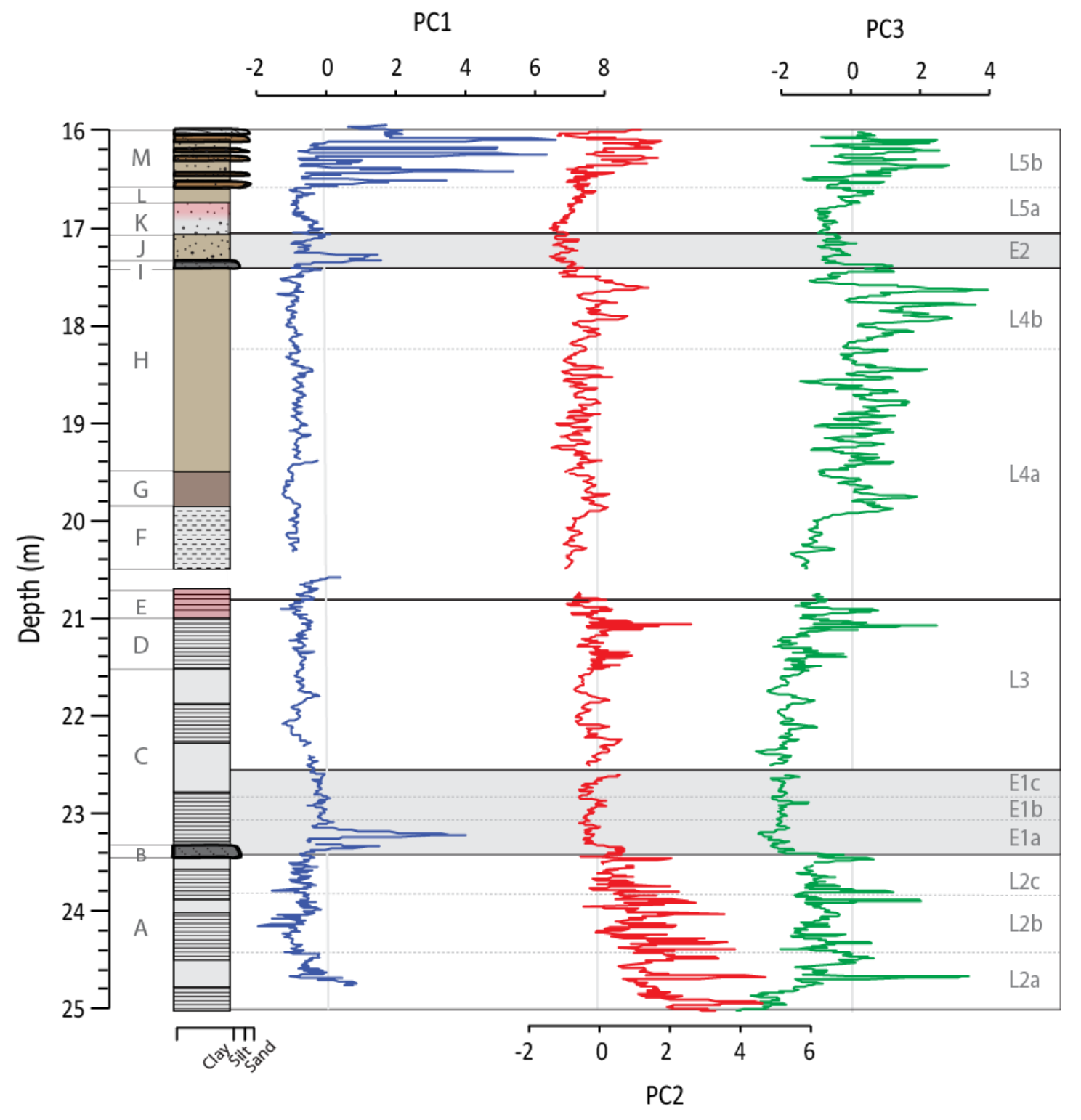

